\title{
فى هذا العدد ..
}

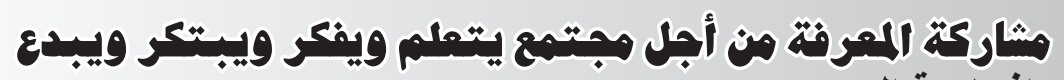

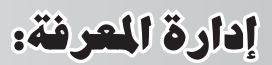

$$
\text { أزمة بمريدة نيويورك تايمز }
$$

$$
\text { هبادرة جوجل }
$$

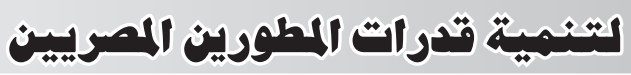

$$
\begin{aligned}
& \text { همايير منظمة اليونسكو العالمية بشأن كثاءة المعلمين في مجال } \\
& \text { تكنولوجيا المعلوهات والاتصال }
\end{aligned}
$$

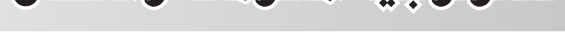

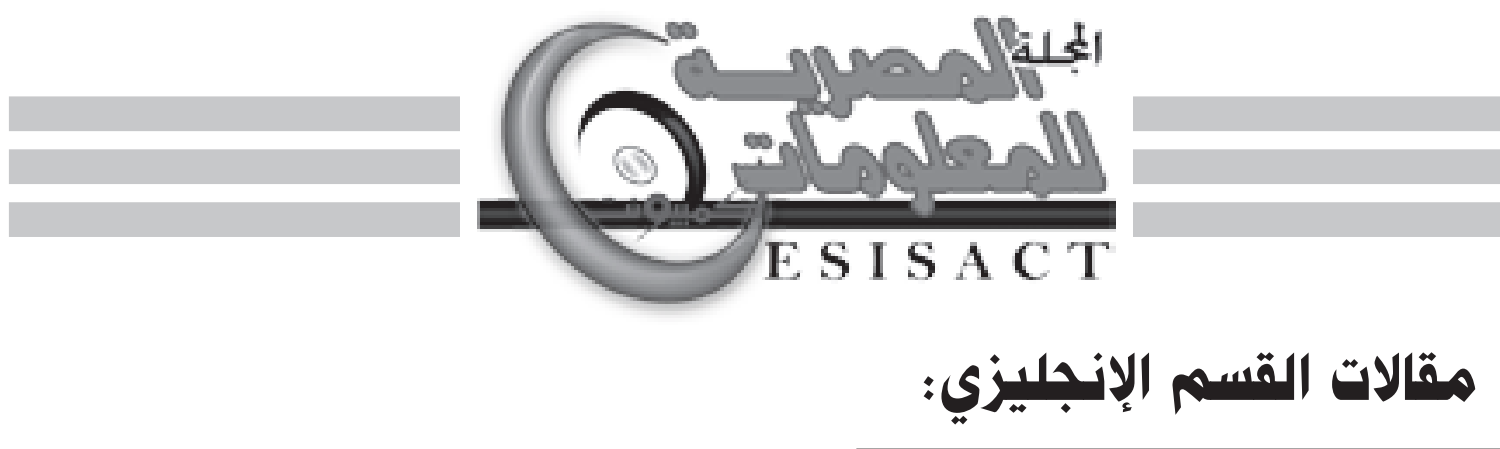

